\title{
Penerapan Manajemen Pengetahuan dalam Pengelolaan Dokumen di Perpustakaan STIKes Guna Bangsa
}

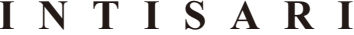

Perpustakaan sebagai sebuah organisasi tidak lepas dari berbagai kegiatan. Dilaksanakannya kegiatan-kegiatan tersebut berimplikasi pada bertambahnya jumlah dokumen, sehingga perpustakaan menemukan permasalahan mengenai pengelolaan dokumen. Sebagai salah satu perpustakaan akademik di Yogyakarta, Perpustakaan STIKes Guna Bangsa juga mengalami persoalan tersebut. Keterbatasan jumlah pustakawan, yang hanya terdiri dari dua pustakawan mengharuskan mereka untuk mengimplementasikan manajemen pengetahuan untuk mengelola dokumendokumen tersebut. Penelitian ini merupakan deskriptif kualitatif. Peneliti menjadi instrumen dalam penelitian ini. Adapun metode pengumpulan datanya adalah wawancara dan observasi. Kedua pustakawan STIKes Guna Bangsa menjadi informan dalam penelitian ini dan peneliti juga melakukan Focus Group Discussion untuk menemukan kesepahaman. Metode analisis datanya meliputi: reduksi data, penyajian data, dan penarikan kesimpulan. Temuan dalam penelitian ini menyatakan bahwa implementasi manajemen pengetahuan berimbas pada meningkatnya kompetensi pustakawan dalam mengelola dokumen. Sejak proses penciptaan pengetahuan dalam siklus pengelolaan dokumen, diperlukan adanya integrasi pengetahuan dengan proses sharing antarperpustakaan, dan adanya standard operating procedure (SOP) yang terlahir karena proses tersebut. Dua hal yang menjadi catatan dalam hal ini adalah minimnya SDM serta minimnya infrastruktur. Keduanya menjadi tantangan atas kegiatan implementasi manajemen pengetahuan.

\section{$\begin{array}{llllllll}A & B & S & T & R & A & C & T\end{array}$}

Library as an organization cannot be separated from various activities. The implementation of these activities turned out to have implications for increasing the number of documents, so that the library found problems regarding document management. As one of the academic libraries in Yogyakarta, the STIKes Guna
PENULIS

Thoriq Tri Prabowo

Universitas Islam Negeri
Sunan Kalijaga
Yogyakarta

toriq.prabowo@uin-suka.ac.id

KATA KUNCI

berbagi pengetahuan, manajemen dokumen, manajemen pengetahuan

KEY WORDS

management,

knowledge management, knowledge sharing 
Bangsa Library also experiences this problem. The limited number of librarians, which consists of only two librarians requires them to implement knowledge management to manage the documents. This research is a qualitative descriptive study. The researcher became an instrument in this study. The data collection methods are interviews and observations. The two STIKes Guna Bangsa librarians were informants in this study and the researchers also conducted Focus Group Discussions to find understanding. Data analysis methods include: data reduction, data presentation, and drawing conclusions. The findings in this study state that the implementation of knowledge management has an impact on increasing the competence of librarians in managing documents. Since the process of creating knowledge in the document management cycle, it is necessary to integrate knowledge with the process of sharing between libraries, and the existence of standard operating procedures (SOPS) that were born because of this process. Two things to note in this case are the lack of human resources and the lack of infrastructure. Both are challenges for the implementation of knowledge management.

\section{PENGANTAR}

\section{Latar Belakang Masalah}

Perpustakaan sebagai sebuah organisasi pasti menghadapi permasalahan dalam proses mencapai visi dan misinya. Permasalahan yang dihadapi perpustakaan relatif sama, hanya saja karena pengetahuan, pengalaman, dan pendidikan di antara pustakawan yang berbeda-beda, maka penanganannya pun relatif berbeda-beda. Pelayanan yang demikian jika tidak dikelola dengan baik dan benar maka akan mengakibatkan tidak tercapainya tujuan organisasi (Rodin, 2013:44).

Pengetahuan dalam hal ini menjadi kunci untuk menyelesaikan permasalahan. Kasus di atas adalah salah satu contoh pentingnya mengimplementasikan manajemen pengetahuan pada sebuah organisasi, terlebih organisasi yang menyediakan jasa yang berhubungan langsung dengan manusia. Pengetahuan dalam memecahkan masalah di organisasi perlu dibagi karena pengetahuan dari masing-masing orang berbeda. Ada banyak kegiatan yang bisa menimbulkan budaya berbagi pengetahuan dalam sebuah organisasi, misal diadakannya rapat rutin dan sistem rolling atau rotasi pegawai (Kurniawati, 2012:296). Kegiatan tersebut akan menjadikan pustakawan terus belajar guna memahami 
segala medan pekerjaan. Dengan terimplementasinya budaya berbagi pengetahuan tersebut maka pekerjaan di perpustakaan dapat dikerjakan dengan efektif dan efisien.

Pada dasarnya manajemen pengetahuan melekat pada semua organisasi (Aldi, 2005:59), termasuk perpustakaan, karena perpustakaan juga merupakan sebuah organisasi. Bahkan, manajemen pengetahuan di perpustakaan disebutkan sebagai aktivitas keseharian perpustakaan ( Rodin, 2013 ). Pengimplementasian manajemen pengetahuan juga berefek baik pada peningkatkan kompetensi personel perusahaan (Lumbantobing, 2011:11-13). Jika diimplementasikan di perpustakaan maka manajemen pengetahuan tersebut akan meningkatkan kompetensi pustakawan. Hal yang dimaksud termasuk pada hal kompetensi dalam pengelolaan dokumen. Dokumen sebagai bukti perkembangan organisasi harus dikelola dengan baik.

Sebelum membahas lebih lanjut mengenai manajemen pengetahuan, Aada beberapa istilah dasar yang perlu diketahui terkait dengan manajemen pengetahuan. Beberapa istilah tersebut adalah: data (data), informasi (information), pengetahuan (knowledge), dan kearifan (wisdom). Data, Informasi, Pengetahuan dan Kearifan saling terkait satu sama lain, bahkan membentuk sebuah hierarki
(Bernstein, 2009:69). Unsur-unsur dasar tersebut perlu dipahami terlebih dahulu.

Pemustaka dari perpustakaan STIKes Guna Bangsa adalah seluruh sivitas akademika STIKes Guna Bangsa, serta pemustaka dari luar dengan kepentingan tertentu. Untuk memanfaatkan fasilitas perpustakaan, pemustaka (sivitas akademika) wajib membawa kartu tanda anggota perpustakaan. Sementara itu, pemustaka dari luar instansi menggunakan surat izin tertentu. Dengan cara demikian pemustaka dapat mengakses fasilitas perpustakaan, yang kebanyakan didominasi oleh aktivitas membaca buku teks. Selain koleksi buku teks, Perpustakaan STIKes Guna Bangsa juga mengoleksi tugas akhir mahasiswa yang berupa karya tulis ilmiah (KTI) untuk program diploma dan skripsi untuk program sarjana. Karya tugas akhir yang diserahkan kepada perpustakaan berupa koleksi tercetak (hardcopy) dan (softcopy) yang dimasukkan dalam kepingan CD.

Mengingat penting dan urgensinya pengelolaan dokumen, maka penelitian ini dirasa perlu dilakukan. Berdasarkan hasil wawancara dengan salah satu Pustakawan STIKes Guna Bangsa, Perpustakaan tersebut sudah menerapkan prinsipprinsip manajemen pengetahuan. Hal tersebut tercermin pada kegiatan-kegiatan rutin di Perpustakaan STIKes Guna Bangsa, seperti rapat rutin evaluasi 
perpustakaan, adanya seminar dan pelatihan untuk meningkatkan kompetensi pustakawan, serta adanya dukungan teknologi informasi yang memadai dalam menunjang hubungan antarpustakawan dan pelayanan perpustakaan.

Seringkali, dokumen yang begitu penting tidak dikelola dengan baik sehingga dalam proses temu kembali dan pelayanan dokumen, pustakawan mengalami kesulitan karena tidak adanya pengelolaan dokumen yang sistematis. Selain itu, permasalahan yang sering muncul dalam pengelolaan dokumen, utamanya apabila dikaitkan dengan persoalan manajemen pengetahuan, adalah adanya pengetahuan dan keterampilan yang berbeda dalam hal pengelolaan dokumen. Ketiadaan kesepemahaman dikhawatirkan akan mengganggu proses pengelolaan dokumen. Hal tersebut sangat riskan dialami Perpustakaan STIKes Guna Bangsa yang hanya memiliki dua pustakawan. Pengelolaan dokumen menjadi sangat susah jika masing-masing pustakawan tidak membagi pengetahuannya.

Perpustakaan STIKes Guna Bangsa sebagai perpustakaan yang juga mengelola dokumen sangat perlu mengimplementasikan pengetahuan untuk mengoptimalkan pengelolaan dokumennya. Penelitian ini bertujuan untuk mengetahui implementasi manajemen pengetahuan dalam pengelolaan dokumen di Perpustakaan STIKes Guna Bangsa.

\section{Rumusan Masalah}

Bagaimanakah implementasi manajemen pengetahuan dalam pengelolaan dokumen di Perpustakaan STIKes Guna Bangsa?

\section{Tujuan Penelitian}

Penelitian ini bertujuan untuk mendeskripsikan implementasi manajemen pengetahuan dalam pengelolaan dokumen di Perpustakaan STIKes Guna Bangsa.

\section{Metodologi Penelitian}

Metode penelitian yang digunakan dalam penelitian ini adalah kualitatif deskriptif. Untuk mendapatkan data, peneliti terjun langsung melakukan observasi secara nonpartisipatif. Pengamatan dilakukan selama dua bulan, yaitu dari bulan November sampai dengan bulan Desember 2019. Adapun yang menjadi informan dalam penelitian ini adalah seluruh pustakawan di Perpustakaan STIKes Guna Bangsa Yogyakarta yang berjumlah dua orang. Peneliti melakukan depth interview dengan kedua pustakawan dengan menggunakan alat pencatat. Setelah 
melakukan transkripsi dan menulisnya dalam sebuah laporan, peneliti melakukan konfirmasi (semacam focus group discussion) dengan kedua pustakawan untuk memastikan bahwa transkrip yang telah direduksi tidak memiliki kesalahan penafsiran. Adapun analisis data dilakukan dengan cara mereduksi seluruh hasil wawancara dan mencocokannya dengan hasil observasi. Ketika keduanya telah memiliki kecocokan, lalu peneliti memutuskannya untuk menggunakan data tersebut sebagai hasil dari analisis data.

\section{Kerangka Pemikiran}

\section{Manajemen Pengetahuan Sebagai Sebuah Konsep}

Sebelum membahas lebih lanjut mengenai manajemen pengetahuan, ada beberapa istilah dasar yang perlu diketahui terkait dengan manajemen pengetahuan. Beberapa istilah tersebut adalah: data (data), informasi (information), pengetahuan (knowledge), dan kearifan (wisdom). Data, Informasi, Pengetahuan dan Kearifan saling terkait satu sama lain, bahkan membentuk sebuah hierarki (Bernstein, 2009:69). Unsur-unsur dasar tersebut perlu dipahami terlebih dahulu.

Data (data) adalah sebuah produk pengamatan yang tidak memiliki makna sebelum diproses. Hasil olahan data akan menjadi informasi. Information (informasi) merupakan hasil olahan data yang bisa digunakan untuk menjawab sebuah pertanyaan. Knowledge (pengetahuan) adalah kemampuan untuk mentransformasikan informasi menjadi sebuah instruksi yang memungkinkan manusia untuk mengontrol sesuatu; dan Wisdom (kearifan) adalah kemampuan untuk melihat konsekuensi jangka panjang dari tindakan apapun yang didasarkan pada pengetahuan. Wisdom juga mencakup evaluasi dari apa yang sudah dikerjakan(Bernstein, 2009:69).

Manajemen banyak dibahas dalam berbagai bidang ilmu, salah satunya adalah ilmu perpustakaan. Manajemen dalam konteks perpustakaan merupakan serangkaian kegiatan mengkoordinasi manusia, informasi, sumber daya teknis dan keuangan sebuah organisasi untuk mencapai tujuannya (Jo, 1990:4). Secara umum, pengetahuan diartikan sebagai hal yang biasanya digunakan manusia untuk mengkritik suatu obyjek atau mengambil keputusan dalam aspek apapun di kehidupan manusia (Waltz, 2003:1). Gerard (2006) menyatakan bahwa pengetahuan yang sifatnya explicit (bisa dilihat) hanya $20 \%$, sedangkan yang sifatnya tacit mencapai $80 \%$. Hal tersebut membuktikan bahwa jika pengetahuan bisa dimanfaatkan dengan optimal maka pengetahuan tersebut akan sangat membantu manusia dalam bekerja (Lumbantobing, 2011:10).

Dalam beberapa buku dan tulisan, manajemen pengetahuan memiliki banyak 
definisi. Namun, jika melihat kedua definisi di atas maka bisa dipahami secara literal bahwa manajemen pengetahuan adalah serangkaian kegiatan mengkoordinasi pengetahuan dalam sebuah organisasi (perpustakaan) untuk mencapai tujuannya. Lebih dalam lagi diungkapkan bahwa manajemen pengetahuan adalah suatu aktivitas sistematis yang dilakukan sebuah organisasi untuk berkreasi dan berbagi pengetahuan sehingga pengetahuan tersebut bisa dimanfaatkan untuk mencapai tujuan dari organisasi tersebut (Lumbantobing, 2011). Dalam penelitian ini tujuan yang diharapkan adalah tercapainya tujuan utama perpustakaan, yaitu memenuhi kebutuhan informasi pemustaka sehingga pemustaka merasa puas.

\section{Komponen Manajemen Pengetahuan}

Manajemen pengetahuan memiliki beberapa komponen penting antara lain:

a. Manusia

Manusia dalam hal ini adalah sumber daya manusia yang terlibat dalam sebuah organisasi untuk mencapai tujuan organisasi. Dalam konteks perpustakaan, yang juga merupakan lembaga penyedia jasa informasi memiliki sumber daya profesional yang disebut sebagai pustakawan. Adanya motivasi yang bagus dalam sebuah organisasi untuk membudayakan kegiatan berbagi pengetahuan adalah modal yang $\mathrm{s}$ a $\mathrm{n} \mathrm{g} \mathrm{a} \mathrm{t} \mathrm{b} \mathrm{e} \mathrm{s} \mathrm{a} \mathrm{r} \mathrm{u} \mathrm{n} \mathrm{t} \mathrm{u} \mathrm{k}$ mengimplementasikan manajemen pengetahuan (Lumbantobing, 2011). Pemberian apresiasi kepada pustakawan untuk tidak segan-segan dalam membagi pengetahuannya akan memberikan dampak yang bagus pada perpustakaan. Menganggap pengetahuan sebagai sebuah obyjek yang nyata yang bisa dibagi, dipelajari, dan dilestarikan untuk menyelesaikan permasalahan adalah kunci awal dalam membentuk budaya berbagi pengetahuan (Lumbantobing, 2011:44). Pemberian apresiasi kepada pustakawan untuk tidak segan-segan dalam membagi pengetahuannya akan memberikan dampak yang bagus pada perpustakaan. Menganggap pengetahuan sebagai sebuah obyjek yang nyata yang bisa dibagi, dipelajari dan dilestarikan untuk menyelesaikan permasalahan adalah kunci awal dalam membentuk budaya berbagi pengetahuan(Waltz, 2003:63).

b. Kepemimpinan

Kepemimpinan erat kaitannya dengan shared vision atau kegiatan mengontrol sebuah lembaga agar lurus pada tujuan awalnya. Seorang yang menjadi pemimpin harus mampu mengkolaborasikan elemen-elemen yang ada dalam suatu institusi untuk 
bekerjasama dalam mencapai tujuan (Waltz, 2003:103). Dalam konteks perpustakaan, pemimpin yang dimaksud adalah kepala perpustakaan atau direktur perpustakaan. Kepala perpustakaan yang terbuka akan mampu mengintegrasikan unit-unit yang ada di perpustakaan dengan metode sharing atau bertukar pendapat.

c. Teknologi

Pada era informasi ini banyak sekali teknologi yang mempermudah kegiatan manusia, termasuk dalam hal berbagi pengetahuan. Media sosial bisa menjadi media untuk bertukar informasi di antara pustakawan. Selain sebagai media untuk berkomunikasi dan bertukar pengetahuan, media sosial juga bisa digunakan untuk mendokumentasikan kegiatan yang ada di perpustakaan. Media sosial juga bisa digunakan untuk menyebarluaskan informasi atau berhubungan dengan pemustaka (Forcier, 2013:212). Meskipun biasanya penggunaan teknologi untuk berbagi pengetahuan dilakukan secara nonformal, dampaknya cukup positif untuk menyebarkan pengetahuan, apalagi dengan didukung oleh perangkat mobile yang bisa diakses kapan saja dan dimana saja, sehingga akan sangat mudah bagi sebuah organisasi melakukan persebaran pengetahuan.

d. Organisasi

Perpustakaan sebagai sebuah organisasi yang berkembang perlu belajar pada perusahaan-perusahaan besar yang mampu berkembang dan beradaptasi dengan sangat cepat terhadap perubahan. Organisasi yang menghargai pengetahuan dan gagasan dari sumber daya yang dimilikinya akan menyikapi pengetahuan dan sumber daya yang dimiliki dengan perlakuan yang sangat speesial (Lumbantobing, 2011:16). Sebagai contoh beberapa perusahaan start-up Unicorn mendesain kantor secara kreatif. Selain itu hubungan antara atasan dan bawahan relatif lebih egaliter daripada perusahan konvensional lainnya. Penghargaan terhadap hasil kerja sekecil apapun akan mendapatkan manfaat besar, yaitu kemauan pegawai untuk membagi pengetahuannya secara cuma-cuma (Prabowo, 2016b:154). Pendekatan seperti itu jika diterapkan di perpustakaan sebenarnya sangat memungkinkan. Lingkungan organisasi akan sangat mempengaruhi produksi pengetahuan dan berbagi pengetahuan.

e. Pembelajaran

Pembelajaran organisasi merupakan fenomena sosial karena pengetahuan tersirat (tacit) mendasari 
lahirnya pengetahuan tersurat (explicit) yang dihasilkan secara kolektif melalui proses komunikasi (Yusup, 2012:65). Kegiatan seperti yang dimaksudkan tidak akan serta merta terjadi begitu saja, perlu ada proses pembelajaran di organisasi untuk mencapainya. Proses pembelajaran manajemen pengetahuan dalam sebuah organisasi menjadi sangat penting karena dari berbagi pengetahuanlah akan muncul banyak ide, inovasi, dan pengetahuan baru yang diproduksi guna meningkatkan eksistensinya atas derasnya arus perubahan.

Manajemen pengetahuan adalah sebuah proses sirkulasi antara penciptaan pengetahuan, integrasi, dan diseminasi (Fischer \& Ostwald, 2001:61). Creation secara bahasa diartikan sebagai penciptaan. Dalam konteks sirkulasi pengetahuan di atas, yang dimaksud penciptaan adalah adanya kemauan dari SDM untuk mengeluarkan pengetahuan yang masih bersifat tacit agar bisa digunakan untuk kepentingan organisasi. Setelah pengetahuan muncul dari masingmasing individu maka perlu adanya integrasi antar pengetahuan tersebut untuk menyamakan persepsi agar tidak terjadi kesalahpahaman. Output dari terintegrasinya pengetahuan antaranggota organisasi akan menghasilkan pemecahan masalah yang menguntungkan semua pihak. Jika pemecahan masalah sudah diperoleh, tahap selanjutnya adalah tahap penyebarluasan informasi, karena hasil integrasi pengetahuan tersebut sudah menjadi informasi yang bisa digunakan untuk mengambil keputusan. Prosesnya berjalan begitu seterusnya hingga informasi menjadi pengetahuan yang akan dikelola lagi.

Manajemen pengetahuan dapat diterapkan di berbagai organisasi termasuk perpustakaan karena memiliki manfaat yang signifikan. Secara umum terdapat empat manfaat ketika manajemen pengetahuan diimplementasikan di dalam sebuah organisasi. Keempat manfaat tersebut adalah:

a. Bidang operasi dan pelayanan

Manajemen pengetahuan berfokus pada pengembangan sumber daya manusia, karena pengetahuan mengenai organisasi tersebut berasal dari orang yang memahami organisasi, yaitu sumber daya manusia di organisasi itu sendiri (Sangkala, 2007:36). Proses berbagi pengetahuan yang baik antar-SDM akan meningkatkan koordinasi dan kecakapan dalam memberikan pelayanan yang baik bagi pelanggan. Dalam konteks perpustakaan, semakin besar perpustakaan bergantung pada pengetahuan untuk pengembangan layanan, maka semakin baik juga layanan yang akan dihasilkan. 
b. Bidang pengembangan kompetensi personiel

$$
\text { Dalam Undang-Undang }
$$
Republik Indonesia Nomor 43 Tahun 2007 tentang Perpustakaan Pasal 1 Ayat 8 disebutkan bahwa pustakawan adalah orang yang memiliki kompetensi dalam mengelola perpustakaan. Kompetensi yang dimaksud adalah kompetensi teknis (profesional) dan kompetensi sosial (personal). Hasil penelitian yang dilakukan Crowledy dan Childers (1971) menunjukkan bahwa keakuratan pustakawan referensi dalam memberi jawaban adalah $45 \%$. Nilai tersebut jauh di bawah harapan, karena menunjukkan bahwa layanan referensi tidak efektif sebagai akibat dari kompetensi pustakawan yang buruk (Ralph, 2008:3). Manajemen pengetahuan adalah solusi untuk meningkatkan pelayanan. Dengan kegiatan berbagi pengetahuan maka antara satu individu dengan individu yang lain akan saling mengerti. Sebuah studi menunjukkan bahwa sebuah pelatihan manajemen pengetahuan bisa meningkatkan kompetensi baik teknis maupun sosial. Dengan demikian bisa dipahami bahwa pelatihan manajemen pengetahuan bisa meningkatkan kualitas layanan perpustakaan(Ralph, 2008).

c. Bidang pemeliharaan ketersediaan pengetahuan

Pergeseran dari revolusi industri ke revolusi informasi membuat perubahan besar pada perlakuan terhadap pengetahuan dan informasi. Pengetahuan menjadi aset yang sangat berharga bagi sebuah institusi, khususnya pengetahuan yang tidak termuat dalam dokumen formal (Ugwu \& Ezema, 2010:184). Pada 1929 perbandingan aset tangible (berwujud) dan intangible (tak berwujud/pengetahuan) perusahaan berkisar 70:30. Namun, dampak dari revolusi informasi yang begitu kuat menimbulkan pergeseran yang signifikan. Perbandingan pada 1988 justru berbalik antara yang tangible dan intangible menjadi 70:30 (Sangkala, 2007:37). Artinya sejak terjadinya revolusi informasi, pengetahuan menjadi aset yang sangat berharga bagi sebuah organisasi agar dikelola dengan baik.

d. Bidang inovasi dan pengembangan produk

Peranan manajemen pengetahuan pada sebuah organisasi dapat dilihat dari implementasi penggunaan pengetahuan sebagai dasar untuk melahirkan inovasi, meningkatkan responsivitas terhadap pelanggan (pemustaka), dan meningkatkan produktivitas kerja (Sangkala, 2007:38). Dengan 
dimplementasikannya manajemen pengetahuan secara baik, kemungkinan untuk menghasilkan sebuah inovasi dan pengembangan sangatlah mungkin. Hal tersebut terjadi karena manajemen pengetahuan menyediakan media untuk berkolaborasi dan berbagi pengetahuan (Lumbantobing, 2011:13). Sebagai contoh kartu banyak produk yang diperjualbelikan memiliki layanan keluhan pelanggan. Hal tersebut dimaksudkan untuk mengumpulkan sebanyak mungkin informasi mengenai keluhan agar k e m udia n peru s a ha $n$ mempelajarinya dan membuat inovasi untuk pengembangan produk.

Selain memiliki manfaat, dalam mengimplementasikan manajemen pengetahuan tentu juga memiliki beberapa tantangan. Secara umum, terdapat beberapa tantangan yang menghambat proses manajemen pengetahuan, yaitu:

a. rendahnya keinginan untuk berbagi pengetahuan;

b. rendahnya kepercayaan diri terhadap pengetahuan yang dimiliki yang akan memberi efek pada sebuah organisasi; dan

c. belum tersedianya strategi untuk berbagi pengetahuan di dalam organisasi tersebut(Prabowo, 2016a).

Penelitian ini dirancang untuk m e nge tahui s e ja u h ma a pengimplementasian manajemen pengetahuan digunakan untuk membantu proses pengelolaan dokumen di Perpustakaan STIKes Guna Bangsa yang beralamat di H. Jalan Reingroad Utara, Condongcatur, Depok, Sleman, Daerah Istimewa Yogyakarta (55283). Perpustakaan ini berdiri bersamaan dengan organisasi induknya, yaitu STIKES Guna Bangsa pada tahun 2009. Kini, di tahun 2019, Perpustakaan tersebut memiliki dua orang pustakawan. Perpustakaan tersebut juga mengoleksi beberapa koleksi tercetak dan dalam bentuk kepingan CD. Mayoritas koleksi bersubyjek ilmu kesehatan dengan tiga rumpun besar yaitu- ilmu kebidanan, analis kesehatan, dan ilmu keperawatan. Layanan yang disediakan perpustakaan adalah layanan sirkulasi, referensi, serial, dan fotokopi.

Dokumen adalah semua bentuk informasi (baik berupa kertas maupun elektronik) dan sebagai contoh adalah peta, manuskrip, software komputer (Stevenson \& Collin, 2006:60). Dokumen dan dokumentasi berkaitan sangat erat. Dokumentasi merupakan serangkaian kegiatan pengelolaan dokumen dengan sistematika tertentu sehingga bisa tercapai efektivitas dan efisiensi kerja (Ming-Yueh Tarng \& Han-Yuh Liu, 1994:9). Dengan demikian, manajemen pengetahuan bisa diartikan sebagai pembuatan sistem penyimpanan dan temu kembali dokumen 
(baik berupa dokumen kertas maupun elektronik) secara sistematis (Stevenson \& Collin, 2006:60). Curtin University membuat pedoman penyusunan dokumen kertas yang baik, yaitu dengan pemberian nama file dan pemberian nomor untuk mudah ditemukembalikan (Curtin University, t.t.). Pelayanan dokumen biasanya dilakukan secara tertutup, artinya pemustaka yang membutuhkan akan minta bantuan pustakawan untuk mencarikan dokumen yang dimaksud.

\section{PEMBAHASAN}

\section{Manajemen Pengetahuan dalam}

\section{Perpustakaan STIKes Guna Bangsa}

Berdasarkan hasil pengamatan, beberapa komponen manajemen pengetahuan dalam konteks Perpustakaan STIKes Guna Bangsa adalah sebagai berikut:

a. Sumber Daya Manusia

Perpustakaan STIKes Guna Bangsa memiliki dua pustakawan, yang berpendidikan S1 Ilmu Perpustakaan. Satu di antaranya tengah melanjutkan studi S2 pada program studi Ilmu Perpustakaan dan Informasi. Kedua pustakawan inilah yang melakukan pengelolaan dokumen.

b. Leadership

Sedikitnya SDM yang dimiliki Perpustakaan STIKes Guna
Bangsa memerlukan gaya kepemimpinan yang tepat. Gaya kepemimpinan yang digunakan adalah gaya kepemimpinan terbuka (sharing). Dengan diketahui gaya kepemimpinan yang digunakan, peluang untuk mengimplementasikan manajemen pengetahuan semakin besar, sehingga pengelolaan dokumen juga lebih efektif dan efisien.

c. Teknologi

Dalam hal pengelolaan dokumen, Perpustakaan STIKes Guna Bangsa masih melakukannya secara manual karena dokumen yang dikumpulkan juga relatif masih berwujud kertas. Dokumen tersebut dikumpulkan dalam binder yang dikelompokkan berdasarkan jenis dokumennya. Beberapa dokumen elektronik yang diterima, berdasarkan wawancara, kebanyakan dalam format digital berupa surat elektronik yang diterima melalui email yang diakses menggunakan tiga perangkat komputer.

d. Organisasi

Manajemen pengetahuan melekat pada semua organisasi. Lingkungan organisasi di Perpustakaan STIKes Guna Bangsa merupakan organisasi kecil karena hanya memiliki dua anggota. Berdasarkan struktur organisasi, terlihat bahwa satu orang sebagai 
kepala perpustakaan dan satu orang sebagai staf pada bagian pelayanan. Namun, pada praktiknya kedua pustakawan tersebut saling bekerjasama untuk melakukan pengelolaan dokumen.

e. Learning

Beberapa kegiatan yang bisa dilakukan untuk memperkuat kegiatan manajemen pengetahuan adalah dengan diadakannya pembelajaran. Perpustakaan STIKes Guna Bangsa memberikan perhatian pada pengembangan SDM dengan sering mengikutsertakan pustakawannya dalam seminar, pelatihan, dan sebagainya untuk kemudian pengetahuan yang diperoleh dibagikan kepada organisasi.

\section{Dokumen Yang Dikelola Perpustakaan STIKes Guna Bangsa}

Jika dibedakan berdasarkan intensitas produksi dan penggunaannya, pada dasarnya ada dua jenis dokumen, yaitu dokumen yang intensitas produksinya tinggi, dan dokumen yang diproduksi atau digunakan pada kondisi tertentu. Di bawah ini adalah dokumen yang sering digunakan dan memiliki intensitas produksi yang tinggi (hampir setiap hari):

a. Surat Bebas Pustaka

Surat bebas pustaka di
Perpustakaan STIKes Guna Bangsa diberikan kepada mahasiswa sebagai bukti bahwa mahasiswa tersebut tidak memiliki tanggungan peminjaman, keterlambatan, atau tanggungan penghilangan koleksi perpustakaan. Untuk mendapatkan surat bebas pustaka, mahasiswa harus menyumbangkan tugas akhir dan buku sumbangan yang ditentukan. Surat tersebut biasanya digunakan untuk kepentingan persyaratan yudisium, wisuda, dan pindah.

b. Surat Penyerahan Tugas Akhir Mahasiswa STIKes Guna Banga wajib menyerahkan tugas akhirnya. Mahasiswa program D-3 menyerahkan berupa KTI (Karya Tulis Ilmiah) dan mahasiswa S-1 menyerahkan skripsi kepada perpustakaan, berupa hardcopy dan softcopy. Atas dasar ketentuan tersebut, penyerahan surat tugas akhir diberikan dan diterima oleh perpustakaan.

c. Surat Sumbangan Buku

Surat sumbangan buku diberikan bersamaan dengan surat penyerahan tugas akhir dan surat bebas pustaka dan dibuat juga atas dasar sumbangan buku untuk Perpustakaan STIKes Guna Bangsa yang diberikan oleh mahasiswa sebagai kenangkenangan.

d. Surat Penyerahan Laporan Praktikum 
Surat penyerahan laporan praktikum adalah surat yang diberikan perpustakaan kepada mahasiswa sebagai bukti bahwa mahasiswa telah menyerahkan laporan praktikumnya.

Dokumen-dokumen lain yang diproduksi dan digunakan pada kondisikondisi tertentu adalah:

a. Surat Perjanjian Kerja Sama

Yaitu dokumen yang berisi perjanjian kerja sama antara Perpustakaan STIKes Guna Bangsa dengan insitusi-institusi yang lain. Surat perjanjian kerja sama hanya diproduksi ketika perpustakaan ingin melakukan kerja sama dengan institusi tertentu, ketika sudah ditandatangani oleh pihak kedua, kemudian surat disimpan dalam folder dan diberi t a nda/ 1 abe 1 agar mudah ditemukembalikan.

b. Dokumen Internal Perpustakaan

Dokumen ini meliputi daftar inventaris barang, koleksi, statistik kunjungan perbulan/tahun, visi dan misi, struktur organisasi, program kerja, dan prosedur-prosedur. Dokumen internal perpustakaan diproduksi berdasarkan kebutuhan dan disimpan dalam folder dengan label agar mudah ditemukembalikan.

\section{Implementasi Manajemen}

Pengetahuan Dalam Pengelolaan

Dokumen a. Pengadaan

Pengadaan dokumen yang disebutkan di atas adalah menunggu inisiatif mahasiswa yang membutuhkan. Selain menunggu inisiatif, pustakawan juga memeriksa kembali kepentingan dari mahasiswa pemohon surat.

b. Pengolahan

Langkah-langkah pengelolaan dokumen di Perpustakaan STIKes Guna Bangsa adalah sebagai berikut:

1) Pustakawan membuat formulir dari surat yang dibutuhkan (biasanya sudah tersedia kopiannya);

2) Pustakawan memberikan formulir (formulir rangkap dua, satu untuk arsip perpustakaan dan satu lagi diberikan kepada mahasiswa) tersebut untuk diisi oleh mahasiswa;

3) Pustakawan mengecek kelengkapan formulir, jika dinyatakan tidak lengkap maka pustakawan meminta mahasiswa untuk melengkapinya lagi. Jika formulir sudah lengkap maka pustakawan membubuhkan tanda tangan dan cap;

4) Salah satu formulir diberikan kepada mahasiswa pemohon;

5) Pustakawan memasukkan formulir lainnya yang telah diisi ke dalam binder yang sesuai dengan 
kelompok/klasifikasi suratnya (diurutkan berdasarkan waktu)

c. Pelayanan

Pelayanan dokumen diberikan hanya untuk mengkonfirmasi bagian akademik untuk melanjutkan atau untuk menunda proses pendaftaran yudisium, wisuda, atau pindah. Selain itu, pelayanan dokumen juga diberikan apabila surat yang diterima mahasiswa rusak atau hilang.

d. Pemusnahan

Pemusnahan dokumen dilakukan jika dokumen tersebut sudah berusia lima tahun dari awal penerimaan. Proses pemusnahan dokumen dilakukan oleh pustakawan dengan bantuan asisten kebersihan, tentunya dengan pengawasan pustakawan agar dokumen tidak disalahgunakan.

\section{Proses Manajemen Pengetahuan}

a. Penciptaan Pengetahuan

Berdasarkan hasil wawancara dan observasi, pengetahuan dalam pengelolaan dokumen di Perpustakaan STIKes Guna Bangsa diciptakan oleh dua Pustakawan pertama yang mengelola Perpustakaan STIKes Guna Bangsa. Pengetahuan diciptakan dengan proses diskusi. Pengetahuan dalam mengelola dokumen pada periode 2009-2013 masih disimpan dan ditransfer dengan lisan (oral) saja, dan belum didokumentasikan ke dalam format yang eksplisit. Penulisan pengetahuan yang berupa SOP dilakukan pada 2014, bersamaan dengan penulisan SOP untuk kegiatan-kegiatan yang lain.

b. Integrasi Pengetahuan

Seperti dijelaskan pada proses penciptaan pengetahuan di atas, integrasi pengetahuan dilakukan dengan cara diskusi secara lisan. Diskusi antarpustakawan juga biasanya dilakukan dengan mengirimkan pesan melalui messenger (SMS, BBM, WhatsApp, dan lainnya) jika salah satu pustakawan sedang bertugas di luar Perpustakaan (misalnya, sedang mengikuti seminar, pelatihan, atau sejenisnya).

c. Penyebarluasan Pengetahuan

Pengetahuan pengelolaan dokumen di Perpustakaan STIKes Guna Bangsa Yogyakarta diturunkan pada proses masa percobaan pustakawan baru, yaitu ketika pustakawan baru memasuki masa training, Pengetahuan ditransfer secara turun temurun oleh kepala perpustakaan kepada pustakawan baru. Berdasarkan wawancara, dari awal berdirinya, perpustakaan hanya memiliki dua pustakawan saja. Jika ada satu pustakawan mengundurkan diri dan ada pustakawan baru, proses 
transfer pengetahuan dilakukan, termasuk pengetahuan pengelolaan dokumen.

Penyebarluasan pengetahuan dilakukan dengan dua metode, yaitu melalui lisan dan melalui SOP (Standard Operating Procedure). SOP dibuat lengkap dengan alur kegiatan agar para penerus pengelolaan dokumen mudah mempelajari pengelolaan dokumen di Perpustakaan STIKes Guna Bangsa. SOP tersebut dibuat melalui diskusi dari dua pustakawan sebelumnya, dan jika ada revisi, maka SOP tersebut akan diperbaiki lagi.

\section{Implikasi Implementasi Implikasi \\ Pengimplementasian Manajemen \\ Pengetahuan pada Pengelolaan \\ Dokumen di Perpustakaan STIKes \\ Guna Bangsa}

Sebelum manajemen pengetahuan diimplementasikan di Perpustakaan STIKes Guna Bangsa, pengelolaan dokumen sangat rumit terutama untuk pustakawan baru. Hal ini dikarenakan pustakawan yang baru masuk belum mengetahui tahapan-tahapan pengelolaan dokumen, serta perbedaan penanganan masing-masing dokumen yang berbeda.

Menurut penuturan pustakawan, kemudahan sangat dirasakan setelah Perpustakaan STIKes Guna Bangsa menerapkan manajemen pengetahuan. Dimulai dari berbagi pengetahuan antarpustakawan, sehingga melahirkan satu Standar Operasional Prosedur (SOP) yang bisa dipelajari siapapun, termasuk pustakawan baru. Orang baru yang membaca SOP tersebut pun akan dengan mudah bisa mempelajari dan mempraktikannya.

Pustakawan bisa berdiskusi di mana saja untuk bertukar pengetahuan. Đan Dengan sendirinya hal itu akan direspon sebagai proses kolaborasi pada manajemen pengetahuan. Sejak dilaksanakannya prinsip-prinsip manajemen pengetahuan, sharing dan berbagi pendapat menjadi agenda khusus untuk pustakawan, terutama pustakawan baru, yang akan ditanyai ide-ide dan gagasan untuk mengembangkan perpustakaan. Implikasi dari pengimplementasian manajemen pengetahuan dalam pengelolaan dokumen menjadi sebuah terobosan untuk mengembangkan penyusunan SOP pada kegiatan-kegiatan lain yang dampaknya sangat baik untuk Perpustakaan STIKes Guna Bangsa.

\section{Tantangan}

Minimnya SDM di Perpustakaan STIKes Guna Bangsa menjadikan tidak adanya pustakawan, arsiparis, atau staf khusus yang memiliki standar operasional prosedur (SOP) untuk mengelola dokumen. Pertumbuhan dokumen yang 
relatif terukur membuat pengelolaan dokumen yang saat ini bisa dikatakan mudah, tetapi untuk beberapa waktu yang akan datang akan bisa menjadi boomerang bagi pengelolanya karena lama kelamaan dokumen juga akan tumbuh secara signifikan. Proses manajemen pengetahuan tentu akan tetap berjalan meski hanya dengan dua orang pustakawan, tetapi hal ini lambat laun akan terasa melelahkan bagi pustakawan karena ketidakjelasan SOP dan uraian jabatan antarpustakawan. Kedua pustakawan tersebut berpotensi untuk saling menunjuk ketika mendapatkan tugas pengelolaan dokumen. Tantangan lain lebih pada ketiadaan infrastruktur seperti teknologi dan ruang penyimpanan dokumen yang pertumbuhannya sangat pesat.

\section{KESIMPULAN}

Perpustakaan STIKes Guna Bangsa mengelola beberapa katagori dokumen di antaranya: surat bebas pustaka; surat bukti penyerahan tugas akhir; surat bukti sumbangan buku; dan surat bukti penyerahan laporan praktikum. Pengelolaan dokumen tersebut dimulai dari tahun 2014 dan dilakukan berdasarkan SOP yang dibuat oleh pustakawan. Pembuatan SOP tidak lepas dari permulaan penciptaan pengetahuan dari hanya sekedar diskusi baik secara langsung maupun melalui instant messenger, tetapi dilanjutkan dengan penulisan SOP sebagai acuan untuk pustakawan baru yang mungkin belum memahami pengelolaan dokumen di Perpustakan STIKes Guna Bangsa Yogyakarta. Tantangan-tantangan yang dihadapi adalah permasalahan kurangnya SDM dan ruangan untuk menyimpan dokumen fisik (printed).

Meskipun dalam praktik pengimplementasian manajemen pengetahuan dalam pengelolaan dokumen di Perpustakaan STIKes Guna Bangsa sudah relatif bagus, masih ada beberapa hal yang perlu diperhatikan, yaitu:

a. perlu adanya penambahan SDM pada bagian pengelolaan dokumen atau diperlukan kejelasan uraian jabatan (job description) dari staf yang sudah ada; dan

b. perlu pengadaan infrastruktur untuk mengelola dokumen baik yang berbentuk kertas ataupun elektronik.

\section{DAFTAR PUSTAKA}

Aldi, B. E. (2005). Menjadikan Manajemen Pengetahuan Sebagai Keunggulan Kompetitif Perusahaan Melalui Strategi Berbasis Pengetahuan. Jurnal Studi Manajemen dan Organisasi, 2(1), 58-68.

Bernstein, J. H. (2009). The DataInformation-Knowledge-Wisdom 
Hierarchy and Its Antithesis. NASKO: North American Symposium on Knowledge Organization, 2(1), 68-75.

Curtin University. (t.t.). Using Paper Files. Record and Information Management Curtin Univerity. D i a m b i d a r i https://rim.curtin.edu.au/local/docs UsingPaperFiles.pdf

Fischer, G., \& Ostwald, J. (2001). Knowledge Management: Problem, Promises, Realities, and Challenges. IEEE Intelligent System, 60-73.

Forcier, E. (2013). The Shoemaker's Son: A Substantive Theory of Social Media Use for Knowledge Sharing in Academic Libraries (Theses). School of Library and Information Studies University Alberta, Alberta.

Jo, B. (1990). Effective Library and Information Centre Management. Brookfield: Gower Publishing Company.

Lumbantobing, P. (2011). Manajemen Knowledge Sharing Berbasis Komunitas. Bandung: Knowledge Management Society Indonesia.

Ming-Yueh Tarng, \& Han-Yuh Liu. (1994). Creating Document Management System. Industrial Management and Data System, 94(9), 9-15.

Prabowo, T. T. (2016a). Hubungan Antara Implementasi Manajemen Pengetahuan dan Kompetensi Pustakawan di Perpustakaan UIN Sunan Kalijaga Yogyakarta (Theses). Pascasarjana UIN Sunan Kalijaga, Yogyakarta.

Prabowo, T. T. (2016b). Implementasi Manajemen Pengetahuan di Perpustakaan UIN Sunan Kalijaga Yogyakarta. Jurnal Kajian Informasi dan Perpustakaan, 4(2),
$1 \quad 6 \quad 1$. https://doi.org/10.24198/jkip.v4i2.9 970

Ralph, L. L. (2008). An Investigation of a Knowledge Management Solution for Reference Services (PhD Theses). Graduate School of Computer and Information Sciences Nova Southeastern University, Fort Lauderdale.

Rodin, R. (2013). Penerapan Knowledge Management di Perpustakaan: Studi Kasus di Perpustakaan STAIN Curup. Khizanah AlHikmah, 1(1), 35-46.

Sangkala. (2007). Knowledge Management. Jakarta: Raja Grafindo Persada.

Stevenson, J., \& Collin, P. H. (2006). Dictionary of Information and Library Management Second Edition. London: A \& C Black Publishers.

Kurniawati, S. (2012). Model Penerapan Knowledge Management pada BUMN Penyelenggaraan Bisnis Jasa Telekomunikasi. Jurnal Pendidikan Ekonomi dan Koperasi, 7(1), 285-300.

Ugwu, C. I., \& Ezema, I. J. (2010). Competencies for Successful Knowledge Management Applications in Nigerian Academic Libraries. Journal of Library and Information Science, 2(9), 184-189.

Waltz, E. (2003). Knowledge Management in the Intelligence Enterprise. Norwood: Artech House Information Warfare Library.

Yusup, P. M. (2012). Perspekt if Manajemen Pengetahuan, Informasi, Komunikasi, Pendidikan dan Perpustakaan. Jakarta: Rajawali Pers. 